\title{
The genus Phantolabis (Diptera: Limoniidae) new to the Palearctic: description of a new species and re-definition of the genus
}

\author{
Valentin E. PILIPENKO \\ Lomonosov Moscow State University, GSP-1, Leninskie Gory, Moscow 119991, Russia. \\ Email: vep@mail.ru \\ ๑ https://orcid.org/0000-0002-9384-280X
}

urn:1sid:zoobank.org:author:7D4B4321-A9F7-47C4-9133-46C65781B4FE

\begin{abstract}
A new crane fly species from the genus Phantolabis Alexander, 1956, active in the cold season and previously known by a single, eastern Nearctic species, is described from Primorsky Krai of the Russian Far East. A revised definition of the genus is given.
\end{abstract}

Keywords. Crane flies, Limoniidae, new species, Palearctic, Russian Far East.

Pilipenko V.E. 2021. The genus Phantolabis (Diptera: Limoniidae) new to the Palearctic: description of a new species and re-definition of the genus. European Journal of Taxonomy 746: 148-161.

https://doi.org/10.5852/ejt.2021.746.1327

\section{Introduction}

The diverse and widespread crane fly family Limoniidae Speiser, 1909 includes more than 11000 species in the world fauna. In the Palearctic, the family is represented by 78 genera and more than 1700 species, including 1130 in the eastern Palearctic (Oosterbroek 2020). Recently, the fauna of the eastern Palaearctic Limoniidae has been intensively studied in Korea (Podenas 2013, 2015, 2016a, 2016b, 2016c; Podenas \& Byun 2013, 2014a, 2014b, 2016, 2018; Podenas et al. 2015a, 2015b, 2016, 2017, 2019a, 2019b), China (Mao \& Yang 2009, 2010; Men 2015a, 2015b; Men \& Yu 2015; Zhang et al. 2012, 2014, 2015a, 2015b, 2016, 2019), Mongolia (Podeniene \& Gelhaus 2010, 2015, 2017; Podenas \& Gelhaus 2011; Podenas et al. 2013; Yadamsuren et al. 2015 ) and Japan (Kato et al. 2018).

The fauna of Limoniidae of the Russian Far East has been well studied (Savchenko 1983, 1989; Savchenko \& Krivolutskaya 1976; Pilipenko \& Sidorenko 2006a, 2006b; Pilipenko 2009) and currently includes 56 genera and 415 species (Oosterbroek 2020). Nevertheless, in 2006, a peculiar crane fly species was noticed among the material collected earlier by Evgeniy A. Makarchenko (Russian Academy of Sciences, Far East Branch, Federal Scientific Center of the East Asia Terrestrial Biodiversity). In the early spring of 2015, Dmitry E. Shcherbakov (Borissiak Paleontological Institute, Russian Academy of Sciences) obtained another male of this species from a Malaise trap in the Sikhote-Alin Nature Reserve (Fig. 4), which indicated a wider distribution of this species in Primorsky Krai (Fig. 5). Due to its unusual morphology, which precluded its placement into any known Palearctic limoniid genus, its description was postponed. 
A recent publication by Bouchard \& Gelhaus (2019) provided a redescription and biological data for the little-known Nearctic genus Phantolabis Alexander, 1956 with a single species, Phantolabis lacustris Alexander, 1938, and made it clear that the Russian specimens represented a new species of the same genus.

\section{Material and methods}

The examined material is deposited at the following collections:

JSOC $=$ Jaroslav Starý collection, Olomouc, Czech Republic

$\mathrm{VPMC}=$ private collection of Valentin E. Pilipenko, Moscow, Russia

ZISP $=$ Zoological Institute Russian Academy of Sciences, St. Petersburg, Russia

ZMUM = Zoological Museum of Moscow State University, Moscow, Russia

The holotype and other specimens are preserved in plastic tubes in 70\% ethanol. Two males from the type series were dried and mounted in the course of the study. Colors are described from the dry-mounted specimens. Genitalia of two males and one female were macerated in warm $10 \% \mathrm{KOH}$ for about one hour to remove soft tissues, then rinsed in distilled water. Cleared parts are preserved in glycerol-filled microvials together with the rest of the specimen, in ethanol-filled tubes or pinned below the specimen. The material was studied with an Olympus SZ61 stereo microscope. A Nikon d7000 digital camera, equipped with a Tamron 70-300/4-5,6 and an EL-Nikkor 50/2,8 lenses or a Mitutoyo M Plan Apo 10X and an Olympus ULWD MS Plan 20X microscope objective lenses and controlled by the Helicon Remote ver. 2.6.5.w (https://www.photo-soft.ru/) software, were used to capture stacked images, which were then combined using the Helicon Focus ver. 6.7.1.Pro software (Kozub et al. 2000-2013). The resulting images were processed in Adobe Photoshop CS2. Morphological terminology generally follows McAlpine et al. (1981), except that the notation of wing veins follows The Manual of Afrotropical Diptera (Cumming \& Wood 2017) and the terminology of male terminalia is changed according to Ribeiro $(2006,2008)$ : lobe of gonostylus = inner gonostylus, clasper of gonostylus $=$ outer gonostylus. The general distribution of species is given according to Oosterbroek (2020).

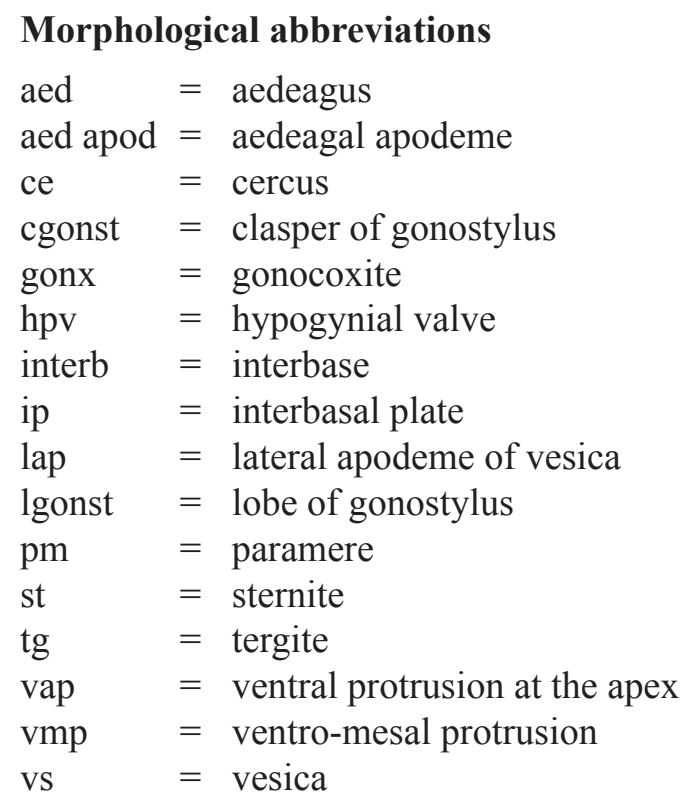




\title{
Results
}

\author{
Class Insecta Linnaeus, 1758 \\ Order Diptera Linnaeus, 1758 \\ Family Limoniidae Speiser, 1909 \\ Subfamily Chioneinae Rondani, 1841 \\ Genus Phantolabis Alexander, 1956
}

\section{Type species}

Erioptera lacustris Alexander, 1938.

\section{Diagnosis}

Small (wing length not exceeding $5.0 \mathrm{~mm}$ ), greyish dark brown species; antenna short, with 11-12 segments, apical flagellomere elongate, formed by fused distal segments. All legs with a short third tarsomere and tarsal claws inserted subapically. Mid and hind tarsi with shortened first and second segments, third tarsomere modified, with keel-like edge. Wings wide with wide anal angle, veins almost without microtrichia, veins $R, C u A$ and $A_{1}$ thickened, arculus poorly visible, cell $R_{3}$ long, with short $R_{2+3+4}$, discal cell open, crossvein $m-m$ absent. Hypopygium not inverted, gonocoxites massive, lobe of gonostylus well developed, with short flat teeth, clasper of gonostylus rod-like, short and inconspicuous. Interbase slender, curved, and needle-like, lateral processes of aedeagal sheath (= parameres) absent. Aedeagus long, straight, thin, divided apically into two or three rods.

Phantolabis glacialis sp. nov. urn:1sid:zoobank.org:act:9E18EC1A-B53A-49E2-989E-1612582E6860

Figs $1-5$

\section{Diagnosis}

Differs from $P$. lacustris by wing venation, structure of male genitalia and ovipositor. Wings entirely brownish, crossvein $r-m$ connecting to $R s$ near wing midlength, apex of $R 3$ bent to costal margin, apical part of vein $C u P$ strongly curving toward wing margin, $A_{1}$ straight, noticeably thickened basally. Gonocoxites massive, with large ventromesal protrusion basally and ventral protrusion apically; lobe of gonostylus well developed, apically with 4-5 small teeth on inner surface; clasper of gonostylus small, situated at base of lobe of gonostylus, plate-like, each with thin apical process; aedeagus relatively thin, long and straight, apically bent upward and divided into two short rods.

\section{Etymology}

The specific Latin epithet 'glacialis' refers to the discovery of this species on ice.

\section{Type material}

\section{Holotype}

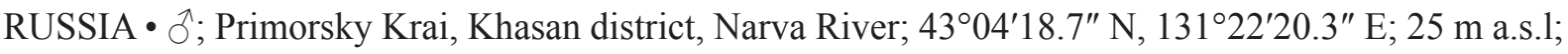
30 Mar. 2001; E.A. Makarchenko leg.; ZISP.

\section{Paratypes}

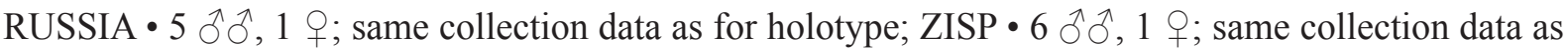
for holotype; ZMUM. 


\title{
Other material
}

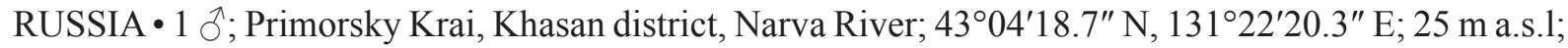

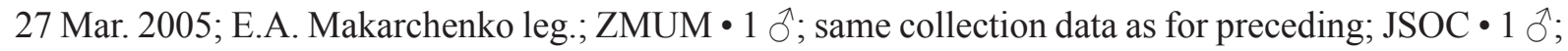
Sikhote-Alin Reserve, Kabaniy Klyuch River; 4453'31.0" N, 135²8'20.0" E; 580 m a.s.1.; 24 Mar.-7 Apr. 2015; D.E. Shcherbakov leg.; Malaise trap; VPMC.

\section{Type locality}

RUSSIA: Primorsky Krai, Khasan district.

\section{Description}

\author{
Male (Figs 1-2)
}

Measurements. Body length 3.5-4.0 mm, wing length 4.5-5.0 mm, length of antennae 0.8-0.9 mm.

HEAD (Fig. 1A-C). Greyish brown; rostrum short, greyish brown, mouth parts yellow; palpi yellow, with 3 oval segments. Antenna yellowish brown. Scape short, widening distally, pedicel oval. Flagellum 9-10-segmented. Basal flagellar segments subcylindrical, more apical ones shorter, ovoid. Distal flagellomere (Fig. 1C) elongate, formed by fused 4-5 distal segments. Verticils short, yellow, approximately half as long as respective segments. Segments covered with short, yellow pubescence.

Thorax (Fig. 1A-B). Dark brown with grey pruinose. Pronotum yellowish brown. Mesonotal prescutum dark brown with grey pruinose, longitudinal stripes broad, indistinct, prescutal pits black, tuberculate pits indistinct. Scutal lobes and scutellum same color as prescutum. Mediotergite brownish grey pruinose. Pleuron brownish grey. Meron not separated by a suture from katepimeron, both midleg and hindleg coxae widely separated.

Legs (Fig. 1E). Coxae and trochanters light brown, femora light brown, tibiae brown without spurs, tarsomeres yellowish brown. Legs covered with very short, semi-erect brown setae. Mid tarsus with shortened first and second segments, third tarsomere short with rounded outgrowth on outer lateral side. Tarsal claws inserted subapically, claw simple, without additional spines, arolium absent.

Wings (Fig. 1D). Wide, brownish, sometimes darkened along $C u A$, veins brownish, almost without macrotrichia. Macrotrichia on wing membrane absent. Venation: arculus absent; $S c$ short, ending about level with midlength of $R s$, stigma indistinct, but costal margin after $S c$ thickened, $s c-r$ indistinct (if present then close to $S c$ tip); origin of $R S$ approximately level with apex of $A_{l} ; R_{l}$ long, apex of $R_{3}$ bent to costal margin; bases of cells $r_{l}$ and $r_{3}$ at same level. Veins $r-m$ and $m$-cu shifted to mid-wing, $r-m$ connecting to $R s$ (not to $R_{4+5}$ as usual) closer to its middle. Discal cell very long and open due to absence of $m-m$. Apical part of $C u P$ strongly bent toward wing margin, $A_{l}$ straight, noticeably thickened basally; anal angle wide, posterior margin widely rounded. Haltere with knob yellowish white.

ABdomen (Fig. 1A). Generally light brown, grey pruinose, covered with rather long, erect, yellow setae; tergites brownish yellow, grey pruinose, lateral and medial stripes missing, posterior margins of tergites greyish. Sternites yellowish grey.

Hypopygium (Fig. 2A-H). Dark brown, grey pruinose. Tergite IX transverse with shallow U-shaped notch. Gonocoxites massive, covered with spike-shaped setae directed laterally, with large ventromesal protrusions basally and ventral protrusions at apex (Fig. 2D). One pair of terminal gonostyli well developed, lobes of gonostyli (Fig. 2G-H), each shaped as triangular-rounded plate, apically with 4-5 small teeth on inner surface. Claspers of gonostyli strongly reduced, poorly visible, each situated at base of adjacent lobe of gonostylus, shaped as small plate, tightly attached to the gonostylus with thin process directed inward. Distal portion of interbase (Fig. 2E-F) simple, appearing as slender 

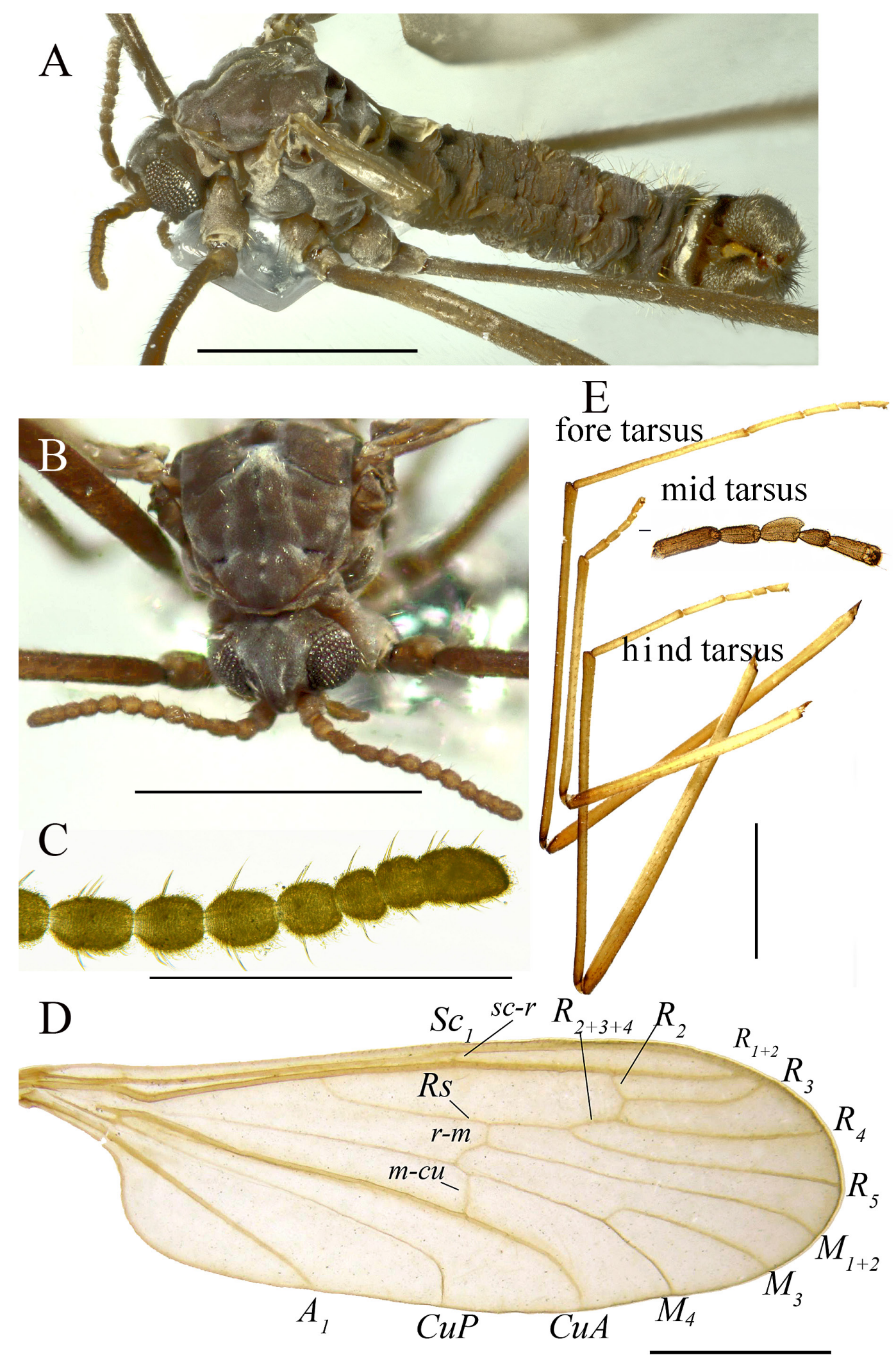

Fig. 1. Phantolabis glacialis sp. nov., paratype, $\widehat{\partial}$, Khasan district, Narva River (ZMUM). A. General view, the left wing is broken. B. Head and thorax. C. Apex of the antenna. D. Wing. E. Legs. Scale bars: $\mathrm{A}-\mathrm{B}, \mathrm{D}=1.0 \mathrm{~mm} ; \mathrm{C}=0.5 \mathrm{~mm} ; \mathrm{E}=5 \mathrm{~mm}$. 

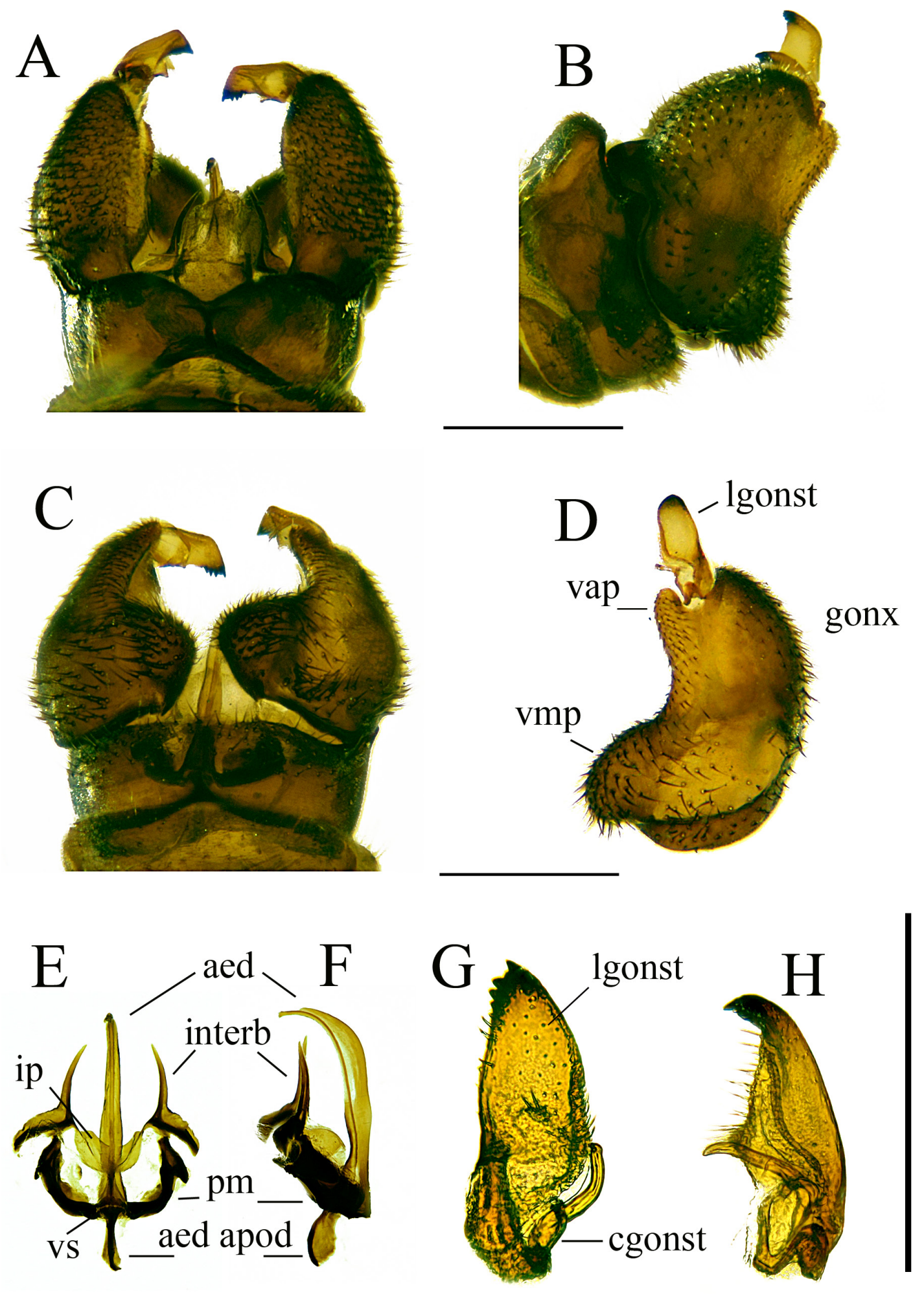

Fig. 2. Phantolabis glacialis sp. nov., paratype, $\widehat{\partial}$, Khasan district, Narva River (ZMUM). Terminalia. A. General dorsal view. B. Lateral view. C. Ventral view. D. Left gonostylus. E. Aedeagal complex, dorsal view. F. Aedeagal complex, lateral view. G. Lobe of gonostylus, lateral view. H. Lobe of gonostylus, dorsal view. Abbreviations: see Material and methods. Scale bars $=1 \mathrm{~mm}$. 
rod gradually narrowing to acute point, basal portions of interbases merge together medially to form separate crescent-shaped plate above aedeagus, referred to here as interbasal plate (ip). Lateral apodeme of paramere poorly developed. Lateral processes of aedeagal sheath absent. Aedeagus relatively thin, long and straight, protruding beyond apices of interbases and reaching approximately to midlength of gonocoxites, apically bent upward and divided into two short rods.

Female (Fig. 3A-F)

Similar to male. Antenna short, with 10 segments.

Female terminalia (Fig. 3B-F) with tergites VIII, IX and X and sternite VIII brown, cerci and hypovalvae brownish yellow. Tergite VIII narrow in lateral aspect, tergite IX triangular, and tergite X relatively small. Cercus elongate, nearly parallel-sided, bent upwards at approximately $2 / 3$ of its length, bluntapexed. Hypovalve long and straight, nearly parallel-sided, setae on dorsal margin long and distinct (Fig. 3E). Tips of hypovalvae reach approximately to $2 / 3$ of cercus length. Two pigmented spermathecae (Fig. 3F).

\section{Elevation}

Specimens were collected at altitudes from approximately 25 to $600 \mathrm{~m}$ a.s.l.

\section{Period of activity}

Adults fly in March-April.

\section{Distribution}

Russia: Primorsky Krai (Fig. 5).

\section{Discussion}

A male of the Nearctic species Phantolabis lacustris was described by Alexander (1938) and assigned to the subgenus Psiloconopa Zetterstedt, 1838 of the genus Erioptera Meigen, 1803. In 1956, this species was transferred to the genus Cryptolabis Osten Sacken, 1860 and a new, monotypic subgenus Phantolabis (Alexander 1956) was created. In a generic key (Alexander \& Byers 1981) it was listed as the genus Phantolabis. In its adult and especially larval (Bouchard \& Gelhaus 2019) characters this genus is close to Hesperoconopa Alexander, 1948 (Alexander 1948, 1952, 1962, 1967, 1976; Savchenko 1980). The Nearctic species of Hesperoconopa have well-developed merons (Bouchard \& Gelhaus 2019), while H. acutistyla Savchenko, 1980 from South Kurils has a reduced meron and tuberculate pits indistinct (Savchenko 1980). In Phantolabis the meron is not separated by a suture from the katepimeron and fuses with the lower portion of the katepimeron to form a composite region referred to by Crampton (1943) as meropleurite or meropleuron. Phantolabis differs in some adult features, such as the antenna with 11-12 segments, the veins almost without microtrichia, and the structure of legs. The hypopygium of Phantolabis differs in the clasper of the gonostylus being strongly reduced and poorly visible. One pair of well-developed interbases are present. The lateral processes of the aedeagal sheath (inner gonapophyses or apophyses according to Alexander) are absent. Aedeagus divided apically into two or three rods. Hesperoconopa (Alexander 1948) has a pair of outer gonostyli (= claspers of gonostyli). It also has well-developed interbases and lateral processes of the aedeagal sheath (or parameres), aedeagus not divided apically. A characteristic biological feature of Phantolabis is the appearance of adults at low temperatures at river banks during the early spring (Bouchard \& Gelhaus 2019).

Phantolabis glacialis sp. nov. is similar to P. lacustris in its general appearance but differs by wing color and venation as well as structures of the male and female terminalia. The wings of both sexes of $P$. glacialis sp. nov. are entirely brownish, while the wings of females of $P$. lacustris have lighter areas 


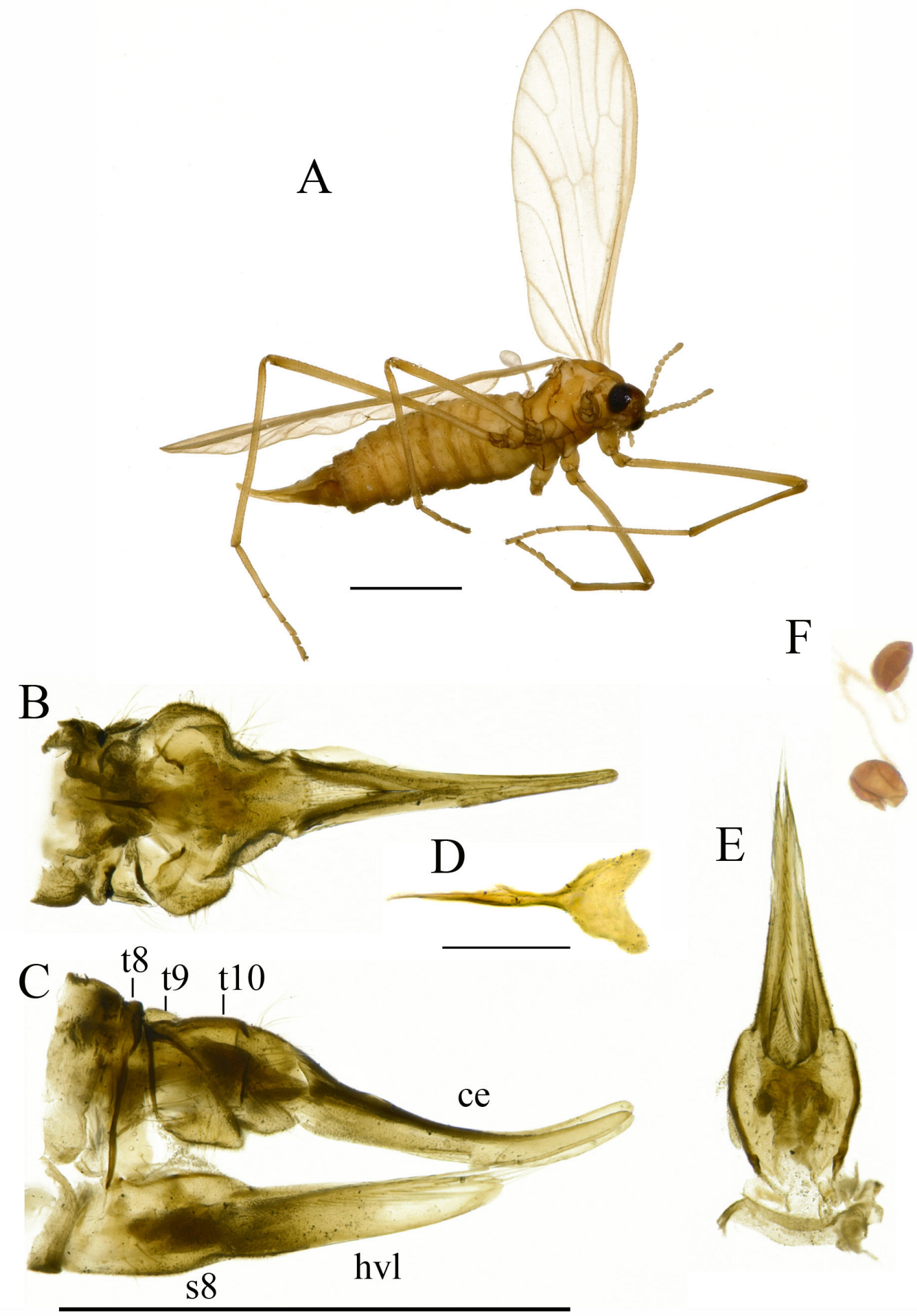

Fig. 3. Phantolabis glacialis sp. nov., paratype, + , Khasan district, Narva River (ZMUM). A. General view of specimen in $70 \%$ ethanol. B-E. Terminalia. B. Tergites VII-X and cercus, ventral view. C. Lateral view. D. Genital fork. E. Sternite VIII and hypogynial valve, dorsal view. F. Spermathecae. Abbreviations: see Material and methods. Scale bars: A-C, E-F $=1.0 \mathrm{~mm} ; \mathrm{D}=0.25 \mathrm{~mm}$. 
in cells $r_{1}, r$, and $m$, and in apical wing cells $r_{3}$ to $m_{4}$ (Bouchard \& Gelhaus 2019). The new species also differs in some venation characters, such as vein $r-m$ connecting to $R s$ some distance before its fork, apex of $R_{3}$ bent to the costal margin, and $C u P$ strongly curving toward the wing margin.

The hypopygium of $P$. glacialis sp. nov. differs by the lobes of the gonostyli apically carrying $4-5$ small teeth on the inner surface, in contrast to "single row of 12-17 short flat teeth along dorsal margin" in $P$. lacustris. The aedeagus of $P$. glacialis sp. nov. is simple, relatively thin, long and straight, apically bent upward and divided into two short rods, while in P. lacustris it is divided from its midlength into 3 closely appressed rods with separated apices (Bouchard \& Gelhaus 2019). The ovipositor of female $P$. glacialis sp. nov. differs from that of $P$. lacustris by the longer cercus, narrow tergite VIII, and two spermathecae (three in P. lacustris).

The larvae of the new species most probably develop in sandy to gravelly bottomed streams (Fig. 4), like those of $P$. lacustris. The adults, too, appear at low temperatures at the banks of small rivers during early spring and possibly during winter thaws. According to the collector Evgeniy A. Makarchenko (pers. com.), the males and females formed aggregations on the underside of ice (as reflected in the species name) hanging over the water. The morphological and ecological features of $P$. glacialis sp. nov. are similar to those of $P$. lacustris (Bouchard \& Gelhaus 2019), indicating that the new species is probably also capable of skating and does not fly. Nevertheless, its flying and skating capabilities both require confirmation by further studies.

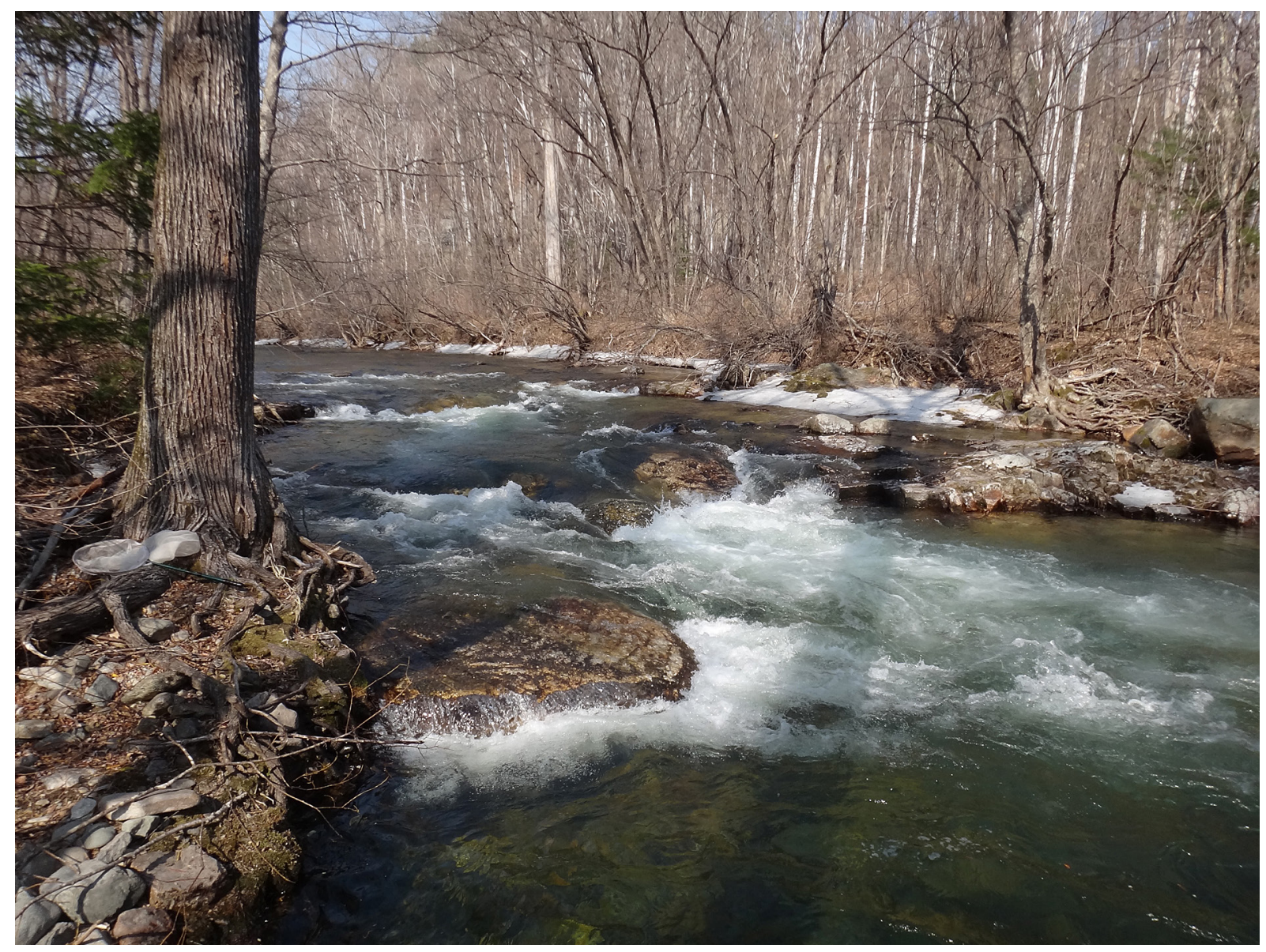

Fig. 4. Habitat of Phantolabis glacialis sp. nov., Russia, Primorsky Krai, Sikhote-Alin Reserve, Kabaniy Klyuch River in April 2015. Photo: D. Shcherbakov. 
Phantolabis lacustris is currently known from the central and eastern parts of the United States and Canada (Bouchard \& Gelhaus 2019). The discovery of the new species in the East Palaearctic suggests that this genus had a wider distribution in the Nearctic in the past and may have crossed Beringia, as also did the genus Hesperoconopa (Savchenko 1980).

\section{Acknowledgements}

I thank the collectors of the new species, who kindly provided the specimens, Evgeniy A. Makarchenko (Russian Academy of Sciences, Far East Branch, Federal Scientific Center of the East Asia Terrestrial Biodiversity) and Dmitry E. Shcherbakov (Borissiak Paleontological Institute, Russian Academy of Sciences), who additionally provided the habitat photo. I am very grateful to Roman Rakitov (Paleontological Institute of Russian Academy of Sciences, Moscow, Russia) for checking and improving the English text, and to Dmitry Gavryushin (Zoological Museum, Moscow Lomonosov State University, Russia) for comments. I also thank Pjotr Oosterbroek for maintaining the very useful Catalogue of the Craneflies of the World (Oosterbroek 2020), Dr Yaroslav Starý (Olomouc, Czech Republic), Prof. Jon K. Gelhaus (Philadelphia, USA), anonymous reviewer, and editors for valuable comments.

\section{References}

Alexander C.P. 1938. New or insufficiently-known crane-flies from the Nearctic region (Diptera, Tipulidae). Part IV. Bulletin of the Brooklyn Entomological Society 33: 71-78.

Alexander C.P. 1948. Records and descriptions of North American crane-flies (Diptera). Part VII. The Tipuloidea of Utah. I. American Midland Naturalist 39: 1-82.

Alexander C.P. 1952. Undescribed species of crane-flies from the western United States and Canada (Dipt.: Tipulidae). Part XIII [part]. Entomological News 63: 233-237.

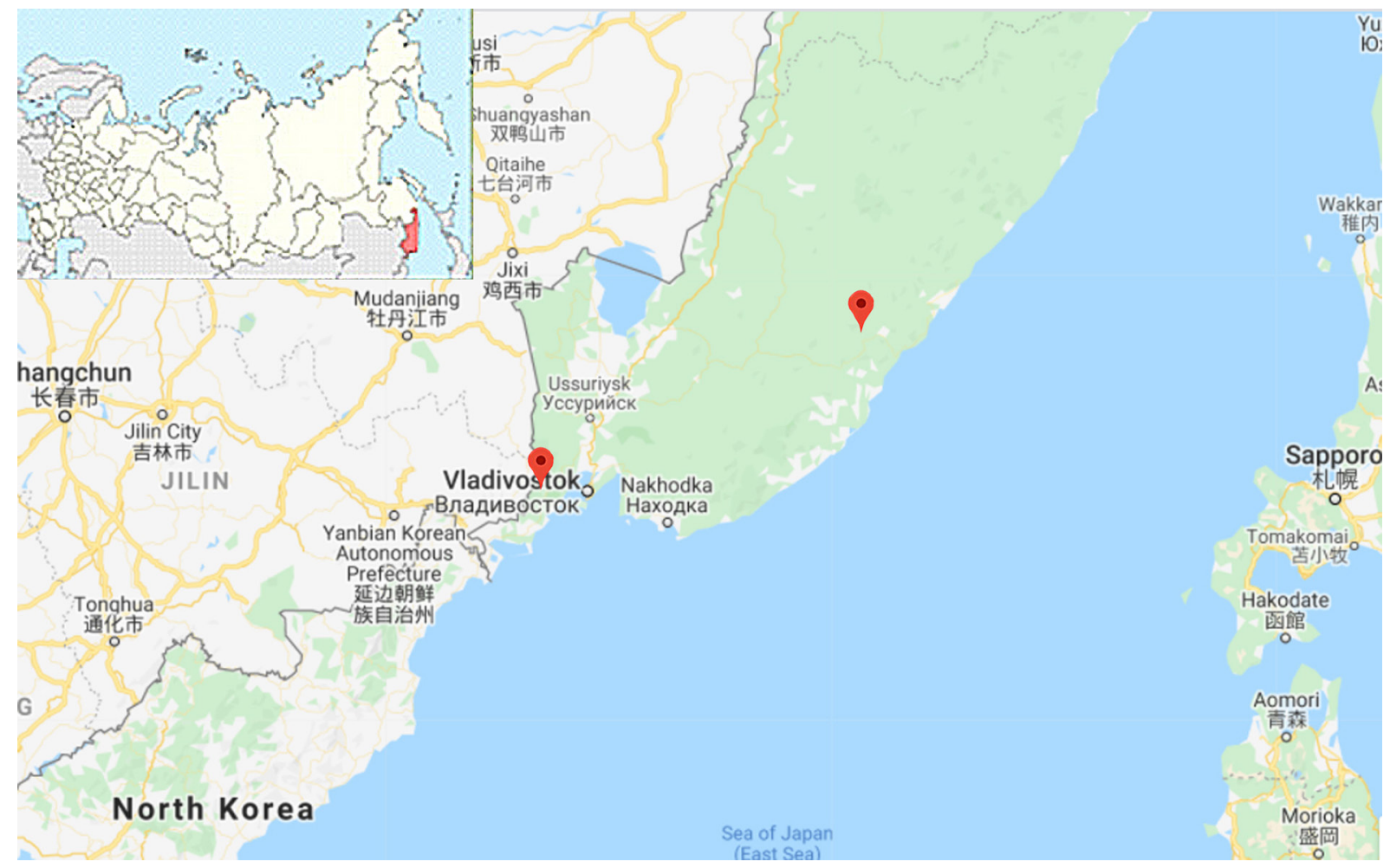

Fig. 5. Distribution of Phantolabis glacialis sp. nov. Map data ${ }^{\circ}$ Google Maps 2020. 
Alexander C.P. 1956. Undescribed species of crane-flies from the eastern United States and Canada (Dipt.: Tipulidae). Part XII. Entomological News 67: 177-185.

Alexander C.P. 1962. New or little-known Tipulidae from eastern Asia (Diptera). XLIX. Philippine Journal of Science 90: 155-214.

Alexander C.P. 1967. The crane flies of California. Bulletin of the California Insect Survey 8: 1-263.

Alexander C.P. 1976. Additions to the crane flies of California (Diptera: Tipulidae). Pan-Pacific Entomologist 52: 244-250.

Alexander C.P. \& Byers G.W. 1981. Tipulidae. In: McAlpine J.F., Peterson B.V., Shewell G.E., Teskey H.J., Vockeroth J.R. \& Wood D.M. (coords) Manual of Nearctic Diptera. Vol. 1: 153-190. Canada Department of Agriculture Research Branch Monograph 27. Ottawa, Ontario.

Available from http://publications.gc.ca/site/eng/9.817747/publication.html [accessed 25 Mar. 2021].

Bouchard R.W. \& Gelhaus J.K. 2019. First record of a skating crane fly: the unusual ecology, behavior, and morphology of Phantolabis lacustris (Alexander, 1938) (Diptera:Limoniidae) with descriptions of the immature stages. Freshwater Science 39: 86-100. https://doi.org/10.1086/707406

Crampton G.C. 1943. The external morphology of the Diptera. Bulletin Connecticut State Geological and Natural History Survey 64: 10-165.

Cumming J.M. \& Wood D.M. 2017. Adult morphology and terminology. Manual of Afrotropical Diptera 1: $89-133$.

Kato D., Tachi T. \& Gelhaus J. 2018. Revision of the subgenus Dicranomyia (Erostrata) Savchenko, 1976 (Diptera, Limoniidae) of Japan. Zootaxa 4441 (1): 181-194. https://doi.org/10.11646/zootaxa.4441.1.11

Kozub D., Khmelik V., Shapoval J., Chentsov V., Yatsenko S., Litovchenko B. \& Starikh V. 2000-2013. Helicon Focus 6.7.1.Pro Helicon Soft Ltd.

Available from http://www.heliconsoft.com/helicon-focus-history-of-changes-win/ [accessed 27 May 2016].

Mao M. \& Yang D. 2009. New species of the genus Epiphragma Osten Sacken from Yunnan, Southwest China (Diptera, Limoniidae). Zootaxa 2121: 44-56. https://doi.org/10.11646/zootaxa.2121.1.5

Mao M. \& Yang D. 2010. Species of the genus Metalimnobia Matsumura from China (Diptera, Limoniidae). Zootaxa 2344: 1-16. https://doi.org/10.11646/zootaxa.2344.1.1

McAlpine J.F. 1981. Morphology and terminology - adults. In: McAlpine J.F., Peterson B.V., Shewell G.E., Teskey H.J., Vockeroth J.R. \& Wood D.M. (eds) Manual of Nearctic Diptera. Vol. 1: 9-63. Canada Department of Agriculture Research Branch Monograph 27. Ottawa, Ontario.

Available from http://publications.gc.ca/site/eng/9.817747/publication.html [accessed 25 Mar. 2021].

Men Q.-L. 2015a. Two new species of the genus Libnotes Westwood (Diptera: Limoniidae) from China, with a key to Chinese species. Zoological Systematics 40: 79-85. https://doi.org/10.11865/zs.20150108

Men Q.-L. 2015b. One new species of the subgenus Eriocera Macquart from China (Diptera: Limoniidae). Entomologica Americana 121: 10-12. https://doi.org/10.1664/14-RA-022.1

Men Q.-L. \& Yu D.-P. 2015. One new species of the subgenus Hexatoma (Eriocera) Macquart (Diptera, Limoniidae) from China, with a key to Chinese species. ZooKeys 477: 157-171.

https://doi.org/10.3897/zookeys.477.7570

Oosterbroek P. 2020. Catalogue of the Craneflies of the World (Diptera, Tipuloidea, Pediciidae, Limoniidae, Cylindrotomidae, Tipulidae). Available from https://ccw.naturalis.nl/ [accessed 16 Jun. 2020]. 
Pilipenko V.E. 2009. Limoniidae. In: Storozhenko S.Y, Sundukov Yu.N., Lelei A.S., Sidorenko V.S., Proshchalykin M.Yu. \& Kupyanskaya A.N. (eds) Insects of Lazovsky Nature Reserve: 331-335. Russian Academy of Science Far Eastern Branch, Institute of Biology and Soil Science, Dal'nauka, Vladivostok. [In Russian.]

Pilipenko V.E. \& Sidorenko V.S. 2006a. Crane-flies (Diptera: Tipulidae, Pediciidae, Limoniidae) of Moneron Island. In: Bogatov V.V., Barkalov V.Y., Lelei A.S., Makarchenko E.A. \& Storozhenko S.Y. (eds) Flora and Fauna of Moneron Island (Materials of International Sakhalin Island Project): 264267. Dal'nauka, Vladivostok. [In Russian.]

Pilipenko V.E. \& Sidorenko V.S. 2006b. Crane-flies (Diptera: Pediciidae, Limoniidae) of Kedrovaya Pad Nature Reserve. In: Makarchenko E.A. (ed.) Flora and fauna of Kedrovaya Pad Nature Reserve: 140-151. Dal'nauka, Vladivostok. [In Russian.].

Podenas S. 2013. Infraorder Tipulomorpha. In: Kim S.-K. (ed.) National List of Species of Korea (Insecta: Diptera I): 1-36. Dongjin Publishing Company, Seoul.

Podenas S. 2015. A new species of Antocha crane fly Osten Sacken, 1860 (Diptera: Limoniidae) for North Korea. Proceedings of the Academy of Natural Sciences of Philadelphia 164: 3-7.

https://doi.org/10.1635/053.164.0102

Podenas S. 2016a. New Geranomyia crane flies (Diptera: Limoniidae) from Korea and Kunashir Island. Zootaxa 4121: 555-565. https://doi.org/10.11646/zootaxa.4121.5.5

Podenas S. 2016b. The crane fly genus Libnotes Westwood, 1876 (Diptera: Limoniidae) for Korea including two new species and an identification key. Zootaxa 4158: 126-136.

https://doi.org/10.11646/zootaxa.4158.1.8

Podenas S. 2016c. New Limoniinae crane flies (Diptera: Limoniidae) of Korea. Zoology and Ecology 27: 47-53. https://doi.org/10.1080/21658005.2016.1260302

Podenas S. \& Byun H.-W. 2013. Antochini crane flies (Diptera: Limoniidae: Limoniinae) of Korea. Journal of Species Research 2: 167-184. https://doi.org/10.12651/JSR.2013.2.2.167

Podenas S. \& Byun H.-W. 2014a. New Limoniinae crane flies (Diptera: Limoniidae) of Korea. Journal of Species Research 3: 167-182. https://doi.org/10.12651/JSR.2014.3.2.167

Podenas S. \& Byun H.-W. 2014b. New species of Antocha Osten Sacken, 1860 crane flies (Diptera: Limoniidae) for South Korea. Zootaxa 3900: 117-126. https://doi.org/10.11646/zootaxa.3900.1.7

Podenas S. \& Byun H.-W. 2016. Metalimnobia crane flies (Diptera: Limoniidae) from Korea. Zootaxa 4132: 330-346. https://doi.org/10.11646/zootaxa.4132.3.2

Podenas S. \& Byun H.-W. 2018. Libnotes crane flies (Diptera: Limoniidae) from Jeju Island (South Korea). Zootaxa 4483: 375-384. https://doi.org/10.11646/zootaxa.4483.2.9

Podenas S. \& Gelhaus J.K. 2011. Three new species of Chioneinae crane flies (Diptera: Limoniidae) from north-central Mongolia. Proceedings of the Academy of Natural Sciences 161: 73-86.

https://doi.org/10.1635/053.161.0105

Podenas S., Gelhaus J.K. \& Podeniene V. 2013. An overview of the Tipulomorpha and Ptychopteromorpha crane flies (Diptera) of Mongolia. Proceedings of the Academy of Natural Sciences of Philadelphia 162: 111-123. https://doi.org/10.1635/053.162.0107

Podenas S., Byun H.-W. \& Kim S.-K. 2015a. New Dicranoptycha Osten Sacken, 1859 crane flies (Diptera: Limoniidae) of North and South Korea. Zootaxa 3925: 257-270.

https://doi.org/10.11646/zootaxa.3925.2.7 
Podenas S., Byun H.-W. \& Kim S.-K. 2015b. Limoniinae crane flies (Diptera: Limoniidae) new to Korea. Journal of Species Research 4: 61-96. https://doi.org/10.12651/JSR.2015.4.2.061

Podenas S., Byun H.-W. \& Kim S.-K. 2016. Rhipidia crane flies (Diptera: Limoniidae) from Korea. Zootaxa 4136: 515-536. https://doi.org/10.11646/zootaxa.4136.3.5

Podenas S., Aukstikalniene R., Byun H.-W., Klein T.A., Kim H.C., Kim T.-W., Kang T.-H. \& Seo H.-Y. 2017. Limoniinae crane flies (Diptera: Limoniidae) new to Korea II. Journal of Species Research 6: 258279. https://doi.org/10.12651/JSR.2017.6.3.258

Podenas S., Sea H.Y., Kim T., Hur J.M., Kim A.-Y., Klein T.A., Kim H.C., Kang T.H. \& Aukstikalniene R. 2019a. Dicranomyia crane flies (Diptera: Limoniidae) of Korea. Zootaxa 4595: 1-110. https://doi.org/10.11646/zootaxa.4595.1.1

Podenas S., Petersen M., Kim A.-Y., Park S.-J., Byun H.-W. \& Seo H.-Y. 2019b. New Lipsothrix (Diptera: Limoniidae) from Korea. Zootaxa 4688: 561-568. https://doi.org/10.11646/zootaxa.4688.4.7

Podeniene V. \& Gelhaus J.K. 2010. The last instar larvae and pupae of Mongolian Limnophilinae crane flies from genera Eloeophila, Limnophila and Phylidorea (Diptera, Limoniidae). Proceedings of the Academy of Natural Sciences of Philadelphia 159: 185-204. https://doi.org/10.1635/053.159.0110

Podeniene V. \& Gelhaus J.K. 2015. Review of the last instar larvae and pupae of Hexatoma (Eriocera) and Hexatoma (Hexatoma) (Diptera, Limoniidae, Limnophilinae). Zootaxa 4021 (1): 93-118.

https://doi.org/10.11646/zootaxa.4021.1.4

Podeniene V. \& Gelhaus J.K. 2017. The first description of the larva and pupa of crane fly genus Phyllolabis Osten Sacken, 1877 (Diptera, Limoniidae, Limnophilinae), with information for understanding the phylogenetic relationships and systematical position of the genus. Zootaxa 4365 (5): 559-570. https://doi.org/10.11646/zootaxa.4365.5.3

Savchenko E.N. 1980. Two genera of limoniid flies (Diptera, Limoniidae) new for the Palaearctic and two new species of these genera. Vestnik Zoologii 1980: 17-25. [In Russian with English summary.]

Savchenko E.N. 1983. Limoniidae of South Primorye. Akademiy Nauk Ukrainskoy SSR, I.I. Schmalhausen Institute of Zoology of Academy of Sciences of Ukraine, Naukova Dumka, Kiev. [In Russian.]

Savchenko E.N. 1989. Limoniid Crane Flies of the USSR Fauna. Naukova Dumka, Kiev. [In Russian.]

Savchenko E.N. \& Krivolutskaya G.O. 1976. Limoniidae of the South Kuril Islands and South Sakhalin. Naukova Dunka, Kiev. [In Russian.]

Yadamsuren O., Hayford B., Gelhaus J., Ariuntsetseg L., Goulden C., Podenas S. \& Podeniene V. 2015. Declines in diversity of crane flies (Diptera: Tipuloidea) indicate impact from grazing by livestock in the Hövsgöl region of Mongolia. Journal of Insect Conservation 19: 465-477.

https://doi.org/10.1007/s10841-015-9767-4

Zhang B., Meng M. \& Yang D. 2019. New species of the subgenus Epiphragma Osten Sacken from China (Diptera, Limoniidae). ZooKeys 876: 39-74. https://doi.org/10.3897/zookeys.876.33163

Zhang X., Wang J. \& Yang D. 2012. Chionea Dalman newly recorded from China with descriptions of two new species (Diptera, Limoniidae). Zootaxa 3316: 1-14. https://doi.org/10.11646/zootaxa.3316.1.1

Zhang X., Li Y. \& Yang D. 2014. A review of the genus Rhipidia Meigen from China, with description of seven new species (Diptera, Limoniidae). Zootaxa 3764: 201-239.

https://doi.org/10.11646/zootaxa.3764.3.2

Zhang X., Li Y. \& Yang D. 2015a. A review of the genus Toxorhina Loew from China, with descriptions of three new species (Diptera, Limoniidae, Limoniinae). ZooKeys 480: 59-80.

https://doi.org/10.3897/zookeys.480.7526 
Zhang X., Li Y. \& Yang D. 2015b. A review of the genus Elephantomyia Osten Sacken from China, with descriptions of two new species (Diptera, Limoniidae). Zootaxa 3919: 553-572.

https://doi.org/10.11646/zootaxa.3919.3.6

Zhang X., Zhang Z. \& Yang D. 2016. Five new species of Geranomyia Haliday, 1833 (Diptera, Limoniidae) from China. Zootaxa 4154: 139-154. https://doi.org/10.11646/zootaxa.4154.2.2

Manuscript received: 24 June 2020

Manuscript accepted: 9 February 2021

Published on: 26 April 2021

Topic editor: Nesrine Akkari

Desk editor: Pepe Fernández

Printed versions of all papers are also deposited in the libraries of the institutes that are members of the EJT consortium: Muséum national d'histoire naturelle, Paris, France; Meise Botanic Garden, Belgium; Royal Museum for Central Africa, Tervuren, Belgium; Royal Belgian Institute of Natural Sciences, Brussels, Belgium; Natural History Museum of Denmark, Copenhagen, Denmark; Naturalis Biodiversity Center, Leiden, the Netherlands; Museo Nacional de Ciencias Naturales-CSIC, Madrid, Spain; Real Jardín Botánico de Madrid CSIC, Spain; Zoological Research Museum Alexander Koenig, Bonn, Germany; National Museum, Prague, Czech Republic. 